\title{
Bacterial Infection in Cystic Fibrosis
}

\author{
J. ROBERT MAY, N. C. HERRICK, and DEIRDRE THOMPSON \\ From the Department of Bacteriology, Institute of Diseases of the Chest, Brompton Hospital, London
}

\begin{abstract}
May, J. R., Herrick, N. C., and Thompson, D. (1972). Archives of Disease in Childhood, 47, 908. Bacterial infection in cystic fibrosis. Tests for precipitins against Staph. aureus, $H$. influenzae, Ps. aeruginosa, Strep. pneumoniae, and Kleb. pneumoniae were carried out on the serum of 195 patients with cystic fibrosis, whose ages ranged from 3 weeks to 31 years. Sputum was obtained for culture from 96 patients over 5 years old. Precipitins against Ps. aeruginosa were more common than those against any other organism, including Staph. aureus, in the 0- to 5- and 6- to 10year-old groups, while mucoid Ps. aeruginosa was the commonest pathogen isolated from the sputum of the 6- to 10-year-old children. These findings suggest that $P s$. aeruginosa is the commonest bronchial pathogen in the younger patients and seem to conflict with the belief that Staph. aureus is always the initial pathogen in cystic fibrosis. Indeed, in 2 patients Ps. aeruginosa was proved to be the initial pathogen, and it is probable that patients with cystic fibrosis are susceptible from birth to bronchial infection by any pathogen with which they come in contact. The prevalence of pseudomonas infection, in contrast to that for staphylococcal or haemophilus infections, fell strikingly in the oldest patients, and this may reflect the failure of many patients with pseudomonas infections to survive into adult life.
\end{abstract}

Staphylococcal infection of the bronchial tree is so common in cystic fibrosis, in contrast to its much less frequent occurrence in other chronic disorders of the lower respiratory tract, that the view is now widely held that unusual susceptibility to bronchial infection by Staph. aureus is a characteristic feature of the condition. Indeed, some authorities believe that the initial lung damage in cystic fibrosis is always brought about by staphylococcal infection and that other respiratory pathogens such as $H$. influenzae, Ps. aeruginosa, and Kleb. pneumoniae can become established only in lungs already damaged in this way. As a corollary, Lawson (1969) believes that prevention of staphylococcal infection in patients with cystic fibrosis will prevent lung damage from occurring and will consequently preclude infection by other pathogens. He therefore prescribes continuous antistaphylococcal chemoprophylaxis for all his patients from the time of diagnosis of cystic fibrosis.

Burns and May (1968) described the occurrence of bacterial precipitins in the serum of 30 patients aged 9 to 28 years with cystic fibrosis and concluded that their findings were in accord with the hypothesis outlined above. This series has now been extended

Received 5 April 1972. to 195 patients, who form the subject of the present report. The findings, however, seem to be no longer compatible with the 'classical' hypothesis and suggest that children with cystic fibrosis are, in fact, abnormally susceptible to any respiratory pathogen from birth.

\section{Material and Methods}

Patients investigated. Serum samples were obtained from patients attending the cystic fibrosis clinics of Dr. J. C. Batten at Brompton Hospital, Dr. D. N. Lawson at Queen Mary's Hospital, Carshalton, Dr. Margaret Mearns at Queen Elizabeth Hospital, Hackney, and Dr. A. P. Norman at The Hospital for Sick Children, Great Ormond Street, London. The youngest patient was aged 3 weeks and the oldest 31 years at the time serum was examined. Sputum samples were also obtained from 96 of the patients aged 6 years or more. Though sputum may be expectorated by children younger than this, none of the 0 - to 5 -year-olds attended the Brompton Hospital and it was not practicable to obtain specimens from children in this age group.

Of the patients in this series, 102 were under the care of Dr. Margaret Mearns and form the subject of an additional report in which bacteriological, clinical, and radiological findings are correlated (Mearns, Hunt, and Rushworth, 1972).

Immunological procedures. Double-diffusion precipitin tests were based on the method described by 
TABLE I

Occurrence Rates of Serum Precipitins in Patients with Cystic Fibrosis

\begin{tabular}{|c|c|c|c|c|c|c|c|c|}
\hline \multirow{2}{*}{ Series } & & & \multirow{2}{*}{$\begin{array}{l}\text { No. of } \\
\text { Patients }\end{array}$} & \multicolumn{5}{|c|}{$\begin{array}{c}\text { Percentage Whose Serum Contained } \\
\text { Precipitins to: }\end{array}$} \\
\hline & & & & $\begin{array}{l}\text { Staph. } \\
\text { aureus }\end{array}$ & $\begin{array}{c}H . \\
\text { influenzae }\end{array}$ & $\begin{array}{l}\text { Ps. } \\
\text { aeruginosa }\end{array}$ & $\begin{array}{l}\text { Strep. } \\
\text { pneumoniae }\end{array}$ & $\begin{array}{l}\text { Kleb. } \\
\text { pneumoniae }\end{array}$ \\
\hline $\left.\begin{array}{l}\text { Present series } \\
\text { Burns and May (1968) } \\
\text { Burns }(1968 b)\end{array}\right\}$ & $\begin{array}{l}\cdots \\
\cdots\end{array}$ & $\begin{array}{l}\cdots \\
\cdots\end{array}$ & $\begin{array}{r}195 \\
30\end{array}$ & $\begin{array}{l}33 \\
53\end{array}$ & $\begin{array}{l}34 \\
80\end{array}$ & $\begin{array}{l}35 \\
33\end{array}$ & $\begin{array}{l}4 \\
6\end{array}$ & $\begin{array}{r}5 \\
10\end{array}$ \\
\hline
\end{tabular}

Burns and May (1967, 1968) and Burns (1968a, b), modified as follows. Each serum was tested neat against antigen extracts of Staph. aureus $(10 \mathrm{mg} / \mathrm{ml}), H$. influenzae $(20 \mathrm{mg} / \mathrm{ml})$, Ps. aeruginosa $(10 \mathrm{mg} / \mathrm{ml})$, Strep. pneumoniae $(2 \mathrm{mg} / \mathrm{ml})$, and Kleb. pneumoniae $(10 \mathrm{mg} / \mathrm{ml})$. These extracts were placed in 5 of the 6 peripheral wells (4 mm diameter) cut in ion agar by a 'hexagon pattern' cutter. The test serum was placed in the central well (13 $\mathrm{mm}$ diameter). The spacing between central and peripheral wells was $6 \mathrm{~mm}$ edge to edge.

In order to determine the specificity of any antibodies detected against $H$. influenzae, Ps. aeruginosa, or Kleb. pneumoniae, immunoelectrophoresis was carried out on double-diffusion positive sera by the method described by Burns and May. In the results recorded below note has been taken only of precipitins specific for each organism. Nonspecific, cross-reacting precipitins have been ignored.

Sputum cultures. Sputum samples were homogenized by digestion with pancreatin before culture (Rawlins, 1953).

\section{Results}

In Table I are compared the overall prevalences of bacterial precipitins in the patients in this series and in those described by Burns and May (1968). The figures for Ps. aeruginosa, Strep. pneumoniae, and Kleb. pneumoniae show only minor differences in the two series, but the larger one shows a considerable reduction in the prevalences of precipitins to Staph. aureus and H. influenzae. The essential difference between the case material comprising the two series is the greater age range covered by the present one. Accordingly the prevalences of precipitins in different age groups in this series have been analysed and the findings are shown in Fig. 1. Three features in particular should be noted. (1) The prevalence of Staph. aureus precipitins increases more or less linearly with age. (2) The prevalence of $H$. influenzae precipitins also increases with age, the rate of increase running closely parallel to that for precipitins to Staph. aureus. (3) Precipitins to Ps. aeruginosa were more common than those to any other organism in the
0- to 5- and 6- to 10-year-olds, but their prevalence remained constant in the 11- to 15- and 16- to 20-year groups and showed a marked fall in the over 21-year group.

Precipitins were found in the serum of 8 out of 39 patients in the 0- to 5-year age group. Of these 8,7 had precipitins to Ps. aeruginosa but none to other organisms, and 1 had precipitins to Staph. aureus only. No patient in this group had precipitins to more than one pathogen.

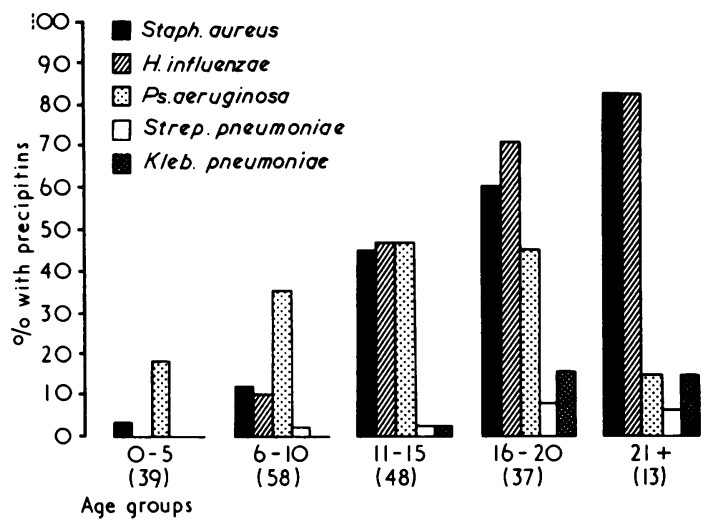

Fig. 1.-Prevalences of antibacterial precipitins in serum of patients with cystic fibrosis. Figures in parentheses indicate number of patients in each group.

Precipitins were found in the serum of 28 out of 58 patients in the 6- to 10-year age group. Of these 28, 21 had precipitins to Ps. aeruginosa, or $H$. influenzae, or Strep. pneumoniae, or combinations of them, but none to Staph. aureus; 3 had precipitins to both Staph. aureus and Ps. aeruginosa; 1 had precipitins to both Staph. aureus and Strep. pneumoniae; while 3 had precipitins to Staph. aureus only.

The isolation rates of bacterial pathogens from sputum are shown in Fig. 2. Only mucoid strains of Ps. aeruginosa have been noted, since these are the strains whose presence in the sputum correlates with 


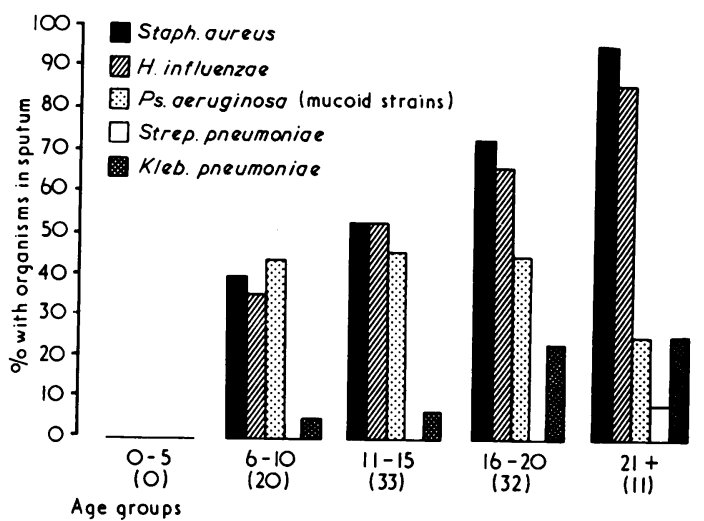

Fig. 2.-Isolation rates of bacterial pathogens from sputum of patients with cystic fibrosis. Figures in parentheses indicate number of patients in each age group.

precipitins in the serum and are hence thought to be pathogenic in chronic respiratory disease (Burns and May, 1968). No sputum was obtained from any patient under 6 years old, but the pattern for the other age groups shows trends similar to those shown by the serum precipitins. Comparison of Fig. 1 and 2, however, indicates that the occurrence of serum precipitins against any organism, except the pneumococcus, was usually lower than the corresponding isolation rate of the organism from sputum. This was to be expected, since there is an inevitable delay in the appearance of precipitins in the serum after the establishment of the organism in the bronchi.

Table II shows the occurrence of serum precipitins and organisms in the sputum at or about the time of death in the 11 patients in the series known to have died.

\section{Discussion}

The 'classical' hypothesis concerning bronchial infection in cystic fibrosis postulates an abnormal susceptibility to Staph. aureus and suggests that the damage caused by infection with this organism renders the lungs susceptible to further infection by other bacterial species. If this hypothesis is correct one would expect that staphylococcal precipitins would appear in the serum of untreated patients earlier than precipitins against other organisms, and that Staph. aureus would be the commonest pathogen in the sputum in the youngest age groups. The trends shown in Fig. 1 and 2 are probably compatible with this expectation in so far as the relation between Staph. aureus, H. influenzae, and Kleb. pneumoniae is concerned, but the relation found between staphylococcal and pseudomonas infections is clearly at variance with it. Thus, in the 0 - to 5 and 6- to 10 -year age groups precipitins against Ps. aeruginosa were found much more commonly than those against Staph. aureus, and Ps. aeruginosa was the commonest species isolated from the sputum in the youngest age group studied (6 to 10 years). Further, none of the 7 patients in the 0 - to 5-year group who had precipitins against pseudomonas had precipitins against staphylococci, and staphylococcal precipitins were found in only one patient in the whole group.

There is a discrepancy, therefore, between the observed findings and those predicted in accordance with the classical hypothesis, but, before discarding this hypothesis, other possible explanations must be considered. For example, staphylococcal precipitins might develop more slowly in response to infection than those against $P s$. aeruginosa, with the result that patients with concurrent infection by both organisms might show precipitins against only

TABLE II

Serum Precipitins and Sputum Culture Findings at or About Time of Death of 11 Patients with Cystic Fibrosis

\begin{tabular}{|c|c|c|c|c|c|c|c|c|c|}
\hline \multirow{2}{*}{ Patient } & \multirow{2}{*}{$\begin{array}{c}\text { Age at } \\
\text { Death } \\
\text { (yr) }\end{array}$} & \multicolumn{4}{|c|}{ Serum Precipitins } & \multicolumn{4}{|c|}{ Sputum Culture } \\
\hline & & $\begin{array}{l}\text { Staph. } \\
\text { aureus }\end{array}$ & $\begin{array}{c}H . \\
\text { influenzae }\end{array}$ & $\begin{array}{c}\text { Ps. } \\
\text { aeruginosa }\end{array}$ & $\begin{array}{c}\text { Kleb. } \\
\text { pneumoniae }\end{array}$ & $\begin{array}{l}\text { Staph. } \\
\text { aureus }\end{array}$ & $\begin{array}{c}H . \\
\text { influenzae }\end{array}$ & $\begin{array}{c}\text { Ps. } \\
\text { aeruginosa }\end{array}$ & $\begin{array}{c}\text { Kleb. } \\
\text { pneumoniae }\end{array}$ \\
\hline $\begin{array}{r}1 \\
2 \\
3 \\
4 \\
5 \\
6 \\
7 \\
8 \\
9 \\
10 \\
11\end{array}$ & $\begin{array}{r}8 \\
11 \\
13 \\
15 \\
16 \\
17 \\
17 \\
18 \\
18 \\
18 \\
19\end{array}$ & $\begin{array}{l}+ \\
- \\
\overline{+} \\
- \\
- \\
- \\
\overline{+} \\
\pm \\
- \\
-\end{array}$ & $\begin{array}{l}- \\
- \\
\overline{+} \\
+ \\
+ \\
+ \\
+ \\
+ \\
+ \\
+ \\
+\end{array}$ & $\begin{array}{l}+ \\
+ \\
+ \\
+ \\
+ \\
+ \\
+ \\
+ \\
+ \\
+ \\
-\end{array}$ & $\begin{array}{l}- \\
- \\
\overline{+} \\
+ \\
\overline{+} \\
\overline{-} \\
\overline{-} \\
\overline{-} \\
+\end{array}$ & $\begin{array}{l}+ \\
+ \\
- \\
+ \\
- \\
- \\
+ \\
- \\
-\end{array}$ & $\begin{array}{l}- \\
+ \\
\overline{-} \\
\overline{-} \\
\overline{-} \\
+ \\
+ \\
+\end{array}$ & $\begin{array}{l}+ \\
+ \\
+ \\
- \\
+ \\
+ \\
+ \\
+ \\
+\end{array}$ & $\begin{array}{l}- \\
+ \\
- \\
+ \\
- \\
- \\
- \\
+ \\
+\end{array}$ \\
\hline
\end{tabular}


the pseudomonas for an appreciable time. In support of this possibility is the observation that in the 6- to 10-year-olds considerably fewer patients with staphylococci in the sputum had corresponding precipitins in the serum than did those with pseudomonas in the sputum (respectively $40 \%: 12 \%$ and $45 \%: 36 \%$-Fig. 1 and 2 ). Even so, it is perhaps surprising that no patients with precipitins against both organisms were found in the 0 - to 5-year group and there were only 3 out of a total of 28 patients with precipitins among the 6- to 10-year-olds.

Secondly, the balance between infection by different bacterial species might have been distorted by the effect of antibacterial drugs. These might be expected to have reduced the prevalence of infection caused by staphylococci relative to those caused by pseudomonas, which are notoriously unresponsive to chemotherapy. For this effect to explain the discrepancy between the classical hypothesis and our observations, it is necessary to postulate that each of the 7 children with pseudomonas precipitins in the 0 - to 5-year group had previously had infections with staphylococci which had been eradicated by the time we carried out our precipitin tests.

Four of these patients were under the care of Dr. Margaret Mearns, from whom we have obtained the following information. (1) One child was diagnosed as having cystic fibrosis after meconium ileus. Repeated deep pharyngeal swabs failed to reveal Staph. aureus, and Ps. aeruginosa was the first pathogen found. (2) The diagnosis of cystic fibrosis was made in the second child at the age of 3 months, and monthly pharyngeal swabs revealed no pathogens until Ps. aeruginosa was isolated at 16 months. (3) Staph. aureus was isolated during the first few weeks after diagnosis of the third child, but subsequently it was replaced by Ps. aeruginosa. (4) In the fourth child Staph. aureus was isolated at the time of diagnosis and persisted in spite of treatment. Subsequently Ps. aeruginosa was found additionally. Thus in 2 of the patients in this group there is clear evidence that the pseudomonas was the initial pathogen, while in the other 2 of Dr. Mearns's patients pseudomonas infection may well have been secondary to staphylococcal damage. We have no information concerning bacteriological findings in the remaining 3 patients in the group.

Though we can cite only the 2 patients mentioned above as incontrovertible examples of initial infection by $P s$. aeruginosa, this at least seems sufficient evidence to conclude that the fundamental susceptibility to bacterial infection in cystic fibrosis relates not only to Staph. aureus. In a retrospective study of treated patients, however, it is impossible to assess the relative importance, as initiators of infection, of the various bacterial species. Even so, we believe that the patterns shown in Fig. 1 and 2 fairly represent the picture and, from our experience, limited to older patients, of antistaphylococcal therapy in cystic fibrosis, we do not think that this has significantly distorted the pattern of infections by different bacterial species. Thus, in patients over 10 years old eradication of staphylococci from the sputum with disappearance of precipitins from the serum is infrequently achieved. In fact we have seen it happen in only 10 of 47 patients studied in detail during the last 3 years. It does not follow that eradication of staphylococci from the respiratory tract of younger patients would be equally difficultindeed, assuming that many of the younger patients would have less lung damage than the ones we studied, it might be expected to be easier. However, the refractoriness of staphylococcal infections to treatment in older patients suggests that eradication of the organism is never likely to be simple, and the pattern of infection in the various age groups provides some support for this view. Thus, the observed incidence of staphylococcal infection increased more or less linearly with age (Fig. 1 and 2), but it is unlikely that such a linear relation would have been found if the patients in the youngest age groups had responded significantly better to therapy than those in the older groups.

We believe, therefore, that contrary to the classical hypothesis children with cystic fibrosis are susceptible from birth to infection of the lower respiratory tract, not only by Staph. aureus, but also by other respiratory pathogens to which they may be exposed. It is pertinent to inquire how the classical hypothesis arose. Cystic fibrosis was first described by Andersen in 1938 and her finding of staphylococcal infection in the patients' lungs was confirmed by later reports (Farber, 1944; di Sant'Agnese and Andersen, 1946; di Sant'Agnese, 1956). So common indeed was staphylococcal bronchopulmonary infection in cystic fibrosis that it came to be regarded as an integral part of the syndrome. Subsequently, in the late 1950s and the 1960s, when infection with Ps. aeruginosa and $H$. influenzae was reported with increasing frequency, it was felt that these infections were secondary to initial staphylococcal ones. It must be remembered, however, that at the time the initial studies of cystic fibrosis were carried out chemotherapy was either not available or used only sparingly, and the large reservoir of potentially pathogenic Ps. aeruginosa seen today among many hospital patients did not exist. Carriage of Staph. 
aureus in the anterior nares, however, was regarded as a normal finding even in the days before chemotherapy (Wilson and Miles, 1964), and it is not surprising that patients, who in reality may have been susceptible to both species, in fact became infected only with staphylococci because it was more or less ubiquitous while pseudomonas was rare. Further, widespread recognition of the importance of $H$. influenzae in chronic respiratory disorders did not occur until the 1950's (Turk and May, 1967), and in the light of the difficulties associated with the isolation of this organism from sputum (May, 1953) it is easy to envisage that its significance may have been overlooked in early studies of cystic fibrosis.

Looked at in another way, it is doubtful whether anyone with no preconceived ideas about the bacteriology of cystic fibrosis would conclude from the figures presented above that there was a special relation between Staph. aureus and cystic fibrosis; rather would he conclude that, though staphylococcal infection is undoubtedly more common than in other lower respiratory disorders, patients with this disease are abnormally susceptible $a b$ initio to infection by any recognized pulmonary pathogens to which they are exposed. If this conclusion is correct, there are two important corollaries. First, as regards chemoprophylaxis, measures directed towards the prevention of staphylococcal infection only will not, we believe, prevent infection by other bacterial species. Prophylaxis should therefore be aimed at preventing infection by any species and, in the absence of a suitable agent for the discouragement of Ps. aeruginosa, uninfected patients should as far as possible be kept out of the hospital environment in order to minimize the risk of crossinfection by virulent strains. Secondly, studies of the nature of the susceptibility of the bronchi to infection in cystic fibrosis must take account not only of staphylococci but of other organisms as well. May and Roberts (1969) reported the preliminary findings of a study of the significance of p-hydroxyphenylacetic acid (p-HPAA) in susceptibility to staphylococcal infection. In the light of the findings of the present investigation, this study is being extended to include other species, and it has been found that Ps. aeruginosa, like Staph. aureus, is capable of utilizing p-HPAA. Details will be reported elsewhere.

Finally, two other features of the figures shown in Table $I$ and Fig. 1 and 2 require comment. First, the occurrence of serum precipitins to pneumococci in the patients in this series was even lower than it was in those described by Burns and May (1968), and the organism was isolated from the sputum of only one patient. It seems likely that the rarity of pneumococcal infection in cystic fibrosis is a byproduct of the antistaphylococcal therapy given to most patients. Secondly, in contrast to the rise in the prevalence of staphylococcal, haemophilus, and klebsiella infections, pseudomonas infections were found much less commonly in the oldest patients than in the 6- to 20-year-olds. This fall in prevalence might be explained by the failure of many patients with pseudomonas infections to survive into adult life, and the findings for the 11 patients in this series who are known to have died (Table II) lend support for this view. 8 of them had specific precipitins to Ps. aeruginosa in the serum while mucoid pseudomonas was found in the sputum of 8 of the 9 patients from whom cultures were made. It may well be, as Doggett and Harrison (1969) suggest, that infection with mucoid Ps. aeruginosa is currently one of the commonest causes of death of patients with cystic fibrosis, and the need to keep them out of hospital away from sources of crossinfection cannot be too strongly emphasized.

We wish to express our thanks to the physicians mentioned above for supplying us with serum and sputum samples from their patients; to Mrs. C. R. Laughton for carrying out the precipitin tests; and to the Cystic Fibrosis Trust for a grant to support N.C.H.

\section{REFERENCES}

Andersen, D. H. (1938). Cystic fibrosis of the pancreas and its relation to celiac disease; a clinical and pathologic study. American Fournal of Diseases of Children, 56, 344.

Burns, M. W. (1968a). Precipitins to pneumococcal C-substance polysaccharide in the serum of patients with chronic bronchial disorders. Lancet, 1, 223.

Burns, M. W. (1968b). Precipitins to klebsiella and other enterobacteria in the serum of patients with chronic respiratory disorders. Lancet, 1, 383.

Burns, M. W., and May, J. R. (1967). Haemophilus influenzae precipitins in the serum of patients with chronic bronchial disorders. Lancet, 1, 354.

Burns, M. W., and May, J. R. (1968). Bacterial precipitins in serum of patients with cystic fibrosis. Lancet, 1, 270.

di Sant'Agnese, P. A. (1956). Cystic fibrosis of the pancreas. American fournal of Medicine, 21, 406.

di Sant'Agnese, P. A., and Andersen, D. H. (1946). Celiac syndrome. IV. Chemotherapy in infections of the respiratory tract associated with cystic fibrosis of the pancreas; observations with penicillin and drugs of the sulfonamide group, with special reference to penicillin aerosol. American fournal of Diseases of Children, 72, 17.

Doggett, R. G., and Harrison, G. M. (1969). Significance of the bacterial flora associated with chronic pulmonary disease in cystic fibrosis. In Proceedings of the 5th International Cystic Fibrosis Conference, Cambridge, September 1969, p. 175 . Ed. by D. Lawson. Cystic Fibrosis Research Trust, London.

Farber, S. (1944). Pancreatic function and disease in early life. V. Pathologic changes associated with pancreatic insufficiency in early life. Archives of Pathology, 37, 238.

Lawson, D. N. (1969). Contribution to panel discussion on microbiology and chemotherapy of the respiratory tract in cystic fibrosis. In Proceedings of the 5th International Cystic Fibrosis Conference, Cambridge, September 1969, p. 225. Ed. by D. Lawson. Cystic Fibrosis Research Trust, London.

May, J. R. (1953). The bacteriology of chronic bronchitis. Lancet, $2,534$.

May, J. R., and Roberts, D. E. (1969). Bronchial infection in cystic fibrosis. Lancet, 1, 602. 
Mearns, M. B., Hunt, G. H., and Rushworth, R. (1972). Bacterial flora of respiratory tract in patients with cystic fibrosis, 19501971. Archives of Disease in Childhood, 47, 902.

Rawlins, G. A. (1953). Liquefaction of sputum for bacteriological examination. Lancet, 2, 538.

Turk, D. C., and May, J. R. (1967). Haemophilus influenzae; Its Clinical Importance, p. 39 . English Universities Press, London.
Wilson, G. S., and Miles, A. A. (1964). Topley and Wilson's Principles of Bacteriology and Immunity, 5th ed. Arnold, London.

Correspondence to Professor J. R. May, Department of Bacteriology, Institute of Diseases of the Chest, Brompton Hospital, Fulham Road, London SW3.

The following articles will appear in future issues of this journal:

Covert Bacteriuria of Childhood: a Clinical and Epidemiological Study. By D. C. L. Savage, M. I. Wilson, M. McHardy, D. A. E. Dewar, and W. M. Fee.

Steroids in Treatment of Pertussis: a Controlled Clinical Trial. By D. Zoumboulakis, D. Anagnostakis, V. Albanis, and N. Matsaniotis.

Massive Pulmonary Haemorrhage in the Newborn: a Changing Pattern. By C. B. Boothby and D. J. deSa.

Plasma Digoxin Levels in Infants. By K. O’Malley, E. N. Coleman, W. B. Doig, and I. H. Stevenson.

Primary Endocardial Fibroelastosis: an Inherited Condition. By A. S. Hunter and A. J. Keay.

Development of Visual Acuity. By G. V. Catford and A. Oliver.

Review Article: Vitamin D Metabolism: Recent Advances. By T. C. B. Stamp.

Muscular Performance in Cystic Fibrosis Patients and its Relation to Vitamin E. By C. W. Darby, A. G. F. Davidson, and I. D. Desai.

Homocystinuria: Reduced Folate Levels During Pyridoxine Treatment. By B. Wilcken and B. Turner. 